\title{
河川流速の自動計測を目標とする 自律移動浮体ロボットの試作開発
}

\author{
PROTOTYPE DEVELOPMENT OF AUTONOMOUS-MOBILE FLOATING- \\ ROBOT FOR AUTOMATIC VELOCITY MEASUREMENT IN NATURAL RIVERS
}

\author{
山上路生 1 ・金子泰洸ポール 2 ・戸田圭一 3 \\ Michio SANJOU, Taikou-Paul KANEKO and Keiichi TODA \\ 1正会員 博(工) 京都大学准教授 工学研究科社会基盤工学専攻（下615-8540 京都市西京区京都大学桂） \\ 2学生会員 京都大学修士課程 工学研究科社会基盤工学専攻 (同上) \\ 3正会員 Ph.D 京都大学教授 工学研究科社会基盤工学専攻（同上）
}

\begin{abstract}
It is of special importance to measure mean velocity and discharge in natural rivers for preventing flood disasters. This study developed autonomous-mobile floating-robot for the purpose of automatic measurement of mean velocity in an open-channel flow. A PID control method could keep the position of the floating-robot against main stream, and then mean velocity could be evaluated reasonably by a rotational speed of screw propeller. Accurate laboratory experiments using LDA provide the calibration curve that connects the propeller speed and mean current velocity. Furthermore, it was recognized that our robot can move successfully in the horizontal plane from the start point to the target one.
\end{abstract}

Key Words : automatic velocity measurement, autonomous mobile robot, PID control and open-channel

\section{1.はじめに}

河川の流量観測とそのデータベース構築は，適切な河 川整備計画や治水事業を進めるにあたって必要不可欠で ある.また河川洪水時においては正確なダム操作が求め られるため，流況のリアルタイム観測は極めて重要であ る. 実河川における流速観測は浮子法1)が最も主流であ るが，浮子が必ずしも主流に追随しないことや，目視の ために計測の主観性が排除できないという課題がある.

このような背景から，様々な方法が提案され実用化に向 けて鋭意研究されている. 今日注目されている手法とし て曳航式浮体に取り付けた計測装置によるものがあげら れる2),3) 。これはADCPを用いるもので水深方向の流速 プロファイルを得ることができるため, 流量の正確な評 価が期待できる，さらに最近では土砂濃度の同時計測手 法も開発されている4).

またビデオカメラや赤外線カメラの画像情報より流速 の瞬時情報を取得する方法も注目されている. 藤田らは PIVを河川流へ適用したLSPIV)やSTIV) とよばれる高精 度画像手法を開発している. さらに悪天候時や夜間でも 映像情報の取得が可能な赤外線カメラを用いた方法は実 用性においてはさらに有利である7。 これらの利点は平 面の流速 2 次元データが得られることであり, 流量観測 に留まらず，ボイル渦に代表される河川の乱流渦の解明 に大きく貢献することが期待され，学術面においても有
用である．電波流速計(8),9)は表面流を対象とするが，天候 や時間帯に左右されず高速流が計測できるメリットがあ り今後のさらなる普及が期待される.

しかしながら，これらの方法はいずれも長所だけでな く解決す心゙き課題も有しており，この短所を補完する新 しい技術や手法の開発が求められる。例えば，曳航式 ADCP法では係留のために観測ポイントが橋梁近くに限 定される. 画像手法では, 計測精度が画質に大きく依存 しデータ信頼性の確認には時間を要することや, 目視で きない暗渠部における観測が難しいことなどの課題があ る. そこで著者は新しい計測手法として，自律移動を可 能とする無人ボートを開発すれば，船体が流れに対して 静止することで推進力から流速を評価できると考えた.

実用化には数年の開発期間を要するが，この発想の可 能性を検証すべく, マイコン制御によって目標地点まで 移動して静止状態を維持できる試作機を作成し, 幅の異 なる2種類の室内実験水路でテストした．機体にはサイ ドスラスタ (スクリュー) を取り付けて横方向移動も可 能とした. 3つのサーボモータによって，水流に対抗す る推進, 横推進および方向舵を独立にPID制御するアル ゴリズムを開発し，室内実験程度の低レイノルズ数流れ では，目標地点で静止させることができた．またレー ザー流速計(LDA)における校正より, 主流速と推進用 モータの回転速度の対応関係が得られ, 本手法によって 流速計測が原理的に可能であることを示した. 


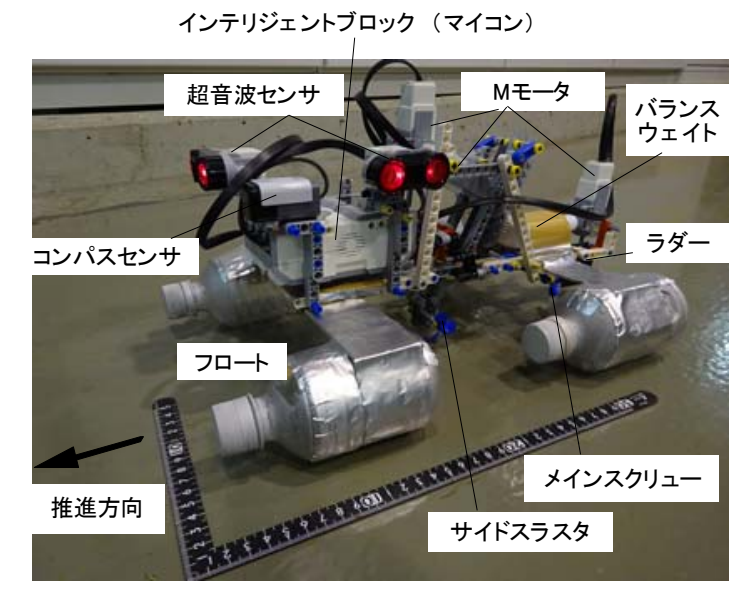

写真-1 浮体ロボット（RX01）外観と構成パーツ

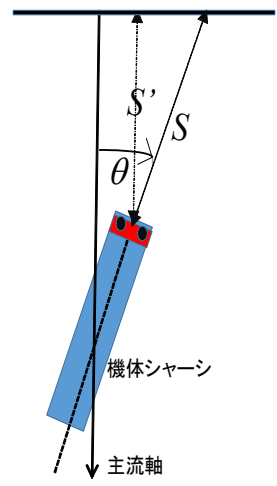

図-1＼cjkstart超音波センサ傾き時の補正

\section{2. ボートロボットの機体駆動と姿勢制御 \\ （1） パワートレインと機体}

写真-1は試作機（Type-RX01）の概観である．全長 $39 \mathrm{~cm}$ ，全幅 $25 \mathrm{~cm}$ である。制御系とシャーシはレゴ社製 のマインドストームEV3のパーツによって組み上げた.

EV3のインテリジェントブロックは各種センサ信号を入 力し，モータへの命令信号を出力できることからロボッ 卜工学の研究教育現場において幅広く利用されている.

試作機には推進用モータにシャフトを介してスク リューを取り付けた．また横方向への移動を可能とする ためにサイドスラスタ（サイドスクリュー）を重心横断 軸近くに付けた。ヨー角（船体の向き）の制御には方向 舵（ラダー）を用い船尾に設置した。なお $1^{\circ}$ 単位で動 作するサーボモータにプラ板製のラダーを取り付けた.

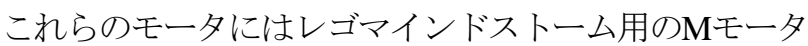

（定格トルク：0.08Nm，停動トルク：0.12Nm）を用い た．推進機構には平ギアを組み合わせてスクリュ一回転 数を25倍（サイドスラスタは5倍）に増速させた．スク

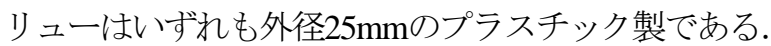

機体の平面位置情報をリアルタイムで取得するために 後述の超音波センサ（レゴ社EV3専用センサ）を2つ （主流方向用，横方向用）取り付けた．また船体の方向 を計測するためにコンパスセンサ（Hitech社）を取り付

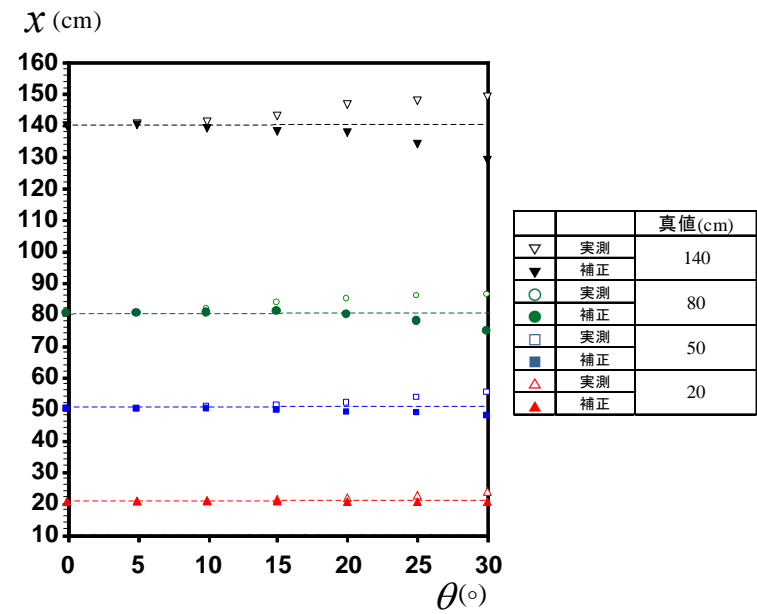

図-2 ヨー角発生時の超音波センサ補正の検証

けた。 フロート部分はヨー安定を期待して双胴型を採用 した．280mlペットボトルを4本使い，2個ずつ前後に配 置した．喫水は4.0cmである.

\section{（2）超音波センサ}

安定かつ正確な自律制御を実現するには信頼性の高い 位置情報の取得が必要である. 本実験では水路に基準面 となる平板を設置し，これに超音波を発信することでx 方向の移動距離や絶対座標を得る．また同時に水路側壁 への超音波発信によって $z$ 方向の位置情報を取得する. 試作機に取り付けたレゴ社の超音波センサは最大 $250 \mathrm{~cm}$ までの距離計測が $1 \mathrm{~mm}$ 解像度で可能である。ここで 問題となるのは機体にヨー角が生じた場合の処理である. 基準板に対して超音波が斜め入射になるため次式による 補正を行った.

$S^{\prime}=S \cos \theta$

ここでSは実測距離值， $S$ 'は補正距離值， $\theta$ はヨー角であ る.この補正を検証するために図-1のように船体を鉛直 方向の重心軸に回転させて実測距離と真值との関係を調 べた．真值は $20 \mathrm{~cm}, 50 \mathrm{~cm}, 80 \mathrm{~cm}$ およ゙ $140 \mathrm{~cm} の 4$ 通り用 意した．図-2に検証結果を示す．対象計測距離が小さい

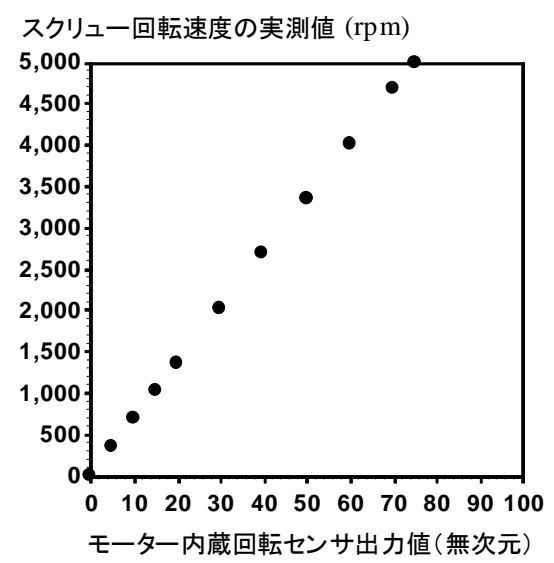

図-3 モータ回転センサとスクリューの回転速度の対応関係 


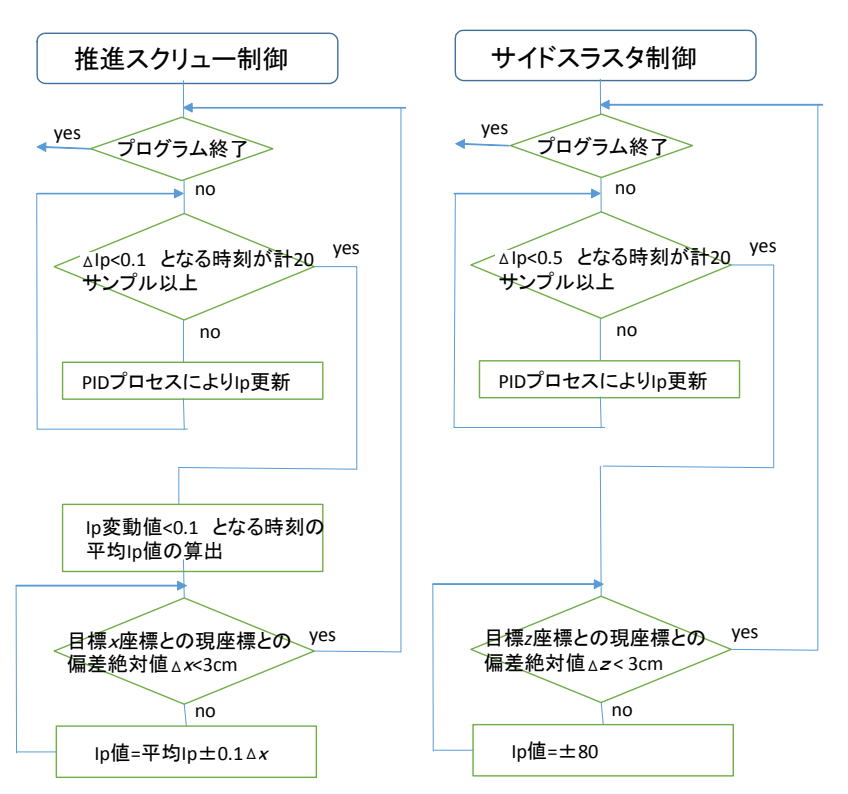

図-4 制御フロー

ほどSおよびS”と真值のずれは小さい，一方で対象距離 が大きいと補正しても真值からのずれは無視できない. またこの傾向はヨー角が大きいほど顕著となる．ただし 機体の静止時の最大瞬間ヨー角は $5 \sim 10^{\circ}$ 程度でありこ の範囲では式(1)の実用性は十分であると考える.

\section{（3）回転速度センサ}

本計測システムでは静止時における推進スクリューの 回転速度から対向流速を評価する. EV3の専用Mモータ には回転速度センサが組み込まれている。このセンサか らは-100から100の範囲をもつ無次元量で信号が出力さ れる，そこで空気中においてスクリュー回転速度を系統 変化させ光学式タコメータによって回転数を実測した. 図-3に実測回転速度とセンサ出力值の関係を示す．線形 関係が得られセンサ值は確かに回転速度を示している. なおモータを逆回転させればセンサ值は負となる。モー 夕回転数を指定するために, 出力值と同様にパワー值と 呼ばれる無次元量(-100〜100)を与える. 入力した值に対 応した回転速度が得られるが，一般に伝達ロス等により 最大值100を入力しても最大出力は得られない. 本結果 でも最大出力は75前後であり，水中ではさらに減少する. 以下この入力無次元量を $I_{p}$, 回転速度センサによる出力 無次元量を $O_{p}$ とよぶ.

\section{3. 制御アルゴリズム}

\section{(1) PID制御}

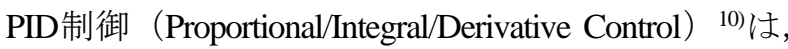
目標值と出力值の偏差に対応させて入力值を決定する比 例操作, 出力值のオフセットを修正する積分操作および
外乱発生時に速やかに出力值を目標值に近づける微分操 作からなる代表的なフィードバック制御である. 本研究 では静止させるためにモータをPID制御した．超音波セ ンサによる時々刻々の静止目標地点からの距離 $x_{n}$ を フィードバックさせて $n$ 時刻における入力值 $I p_{n}$ を次の ように与えた。

$I p_{n}=I p_{n-1}+\Delta I p_{n}$

$\Delta I p_{n}=K_{p}\left(x_{n}-x_{n-1}\right)+K_{i} x_{n}+K_{d}\left\{\left(x_{n}-x_{n-1}\right)-\right.$

$\left.\left(x_{n-1}-x_{n-2}\right)\right\}$

式(2)の右辺第 1 項は比例操作, 第 2 項は積分操作, 第 3 項は微分操作である. ここでは前時刻と現時刻の入力值 の偏差を $\Delta I p_{n}$ とした. $K_{P}, K_{i}$ および $K_{d}$ はそれぞれの操 作パラメータであり, さまざまな最適值の決定法がある が，ここでは系統変化させて選定した。

\section{（2） 全体の制御フロー}

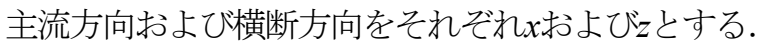
これら2方向の運動をそれぞれ担う推進用スクリューと サイドスラスタおよびラダー角を独立制御する。図-4に スクリューとスラスタの制御フローを示寸.

推進スクリューについては，目標地点への移動の前に， まず現在地点においてPID制御によって静止させる。こ のとき, $\Delta I p_{n}<0.1$ となるサンプル時刻が 20 以上続けば静 止と判定し, この 20 サンプルの平均 $\bar{p}$ を求める. 式(2) のフローに基づけば目標点で静止するはずであるが，数 $10 \mathrm{~cm}$ 程度下流側にずれるため, $|x|$ の0.1倍值をIpに加算 あるいは減算させてスクリュー回転速度を更新し, 目標 地点まで移動させる. $|x|<3 \mathrm{~cm}$ となれば直ちに再び PID制御により静止させる. サイドスラスタについても ほぼ同様の制御フローである。この仕組みでは何らかの 外乱により一旦目標地点から離れてもすぐに戻ることが できる. ラダーについてはコンパスセンサにより読み 取ったヨー角に比例させて1度単位で動作させ，機体が 主流と平行になるように姿勢制御する.

\section{4. 室内水路テスト (40 cm幅水路)}

\section{（1） 実験方法と水理条件}

幅40 cmおよび幅 $150 \mathrm{~cm}$ の 2 種類の可変勾配水路にて試 作機のテストを行った. 制御パラメータの決定や流速と スクリュー回転数の相関関係の検討には，レーザー流速 計（Dantec製 2 成分LDA）による主流速計測を行うため $40 \mathrm{~cm}$ 幅水路を使用した。一方で野外計測では岸部に着 水させた機体を目標計測点まで自動移動させるため, 横 断方向の比較的長い距離の航行が必要とある. 5. で述 べるようにこの平面2次元運動を $150 \mathrm{~cm}$ 幅水路にてテス トした，前述した様に超音波センサによる $x$-z座標位 


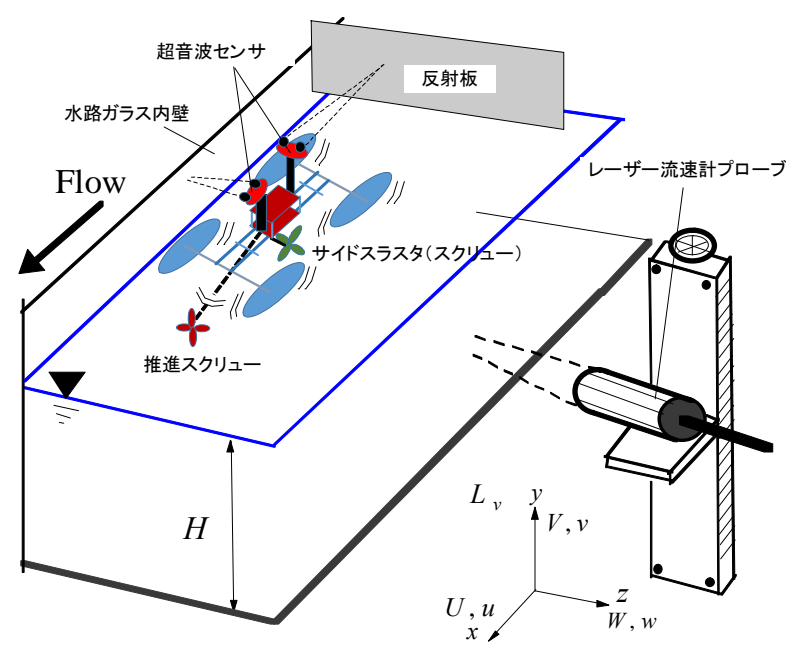

図-5＼cjkstart実験システム

置をリアルタイムに取得する必要がある. $z$ 方向のセン サは水路片側のガラス製内壁に超音波を反射させる．同 様に $x$ 方向のセンサ用に反射板を図-5に示寸通り水路横 断軸に沿って設置した.

$40 \mathrm{~cm}$ 幅水路の実験では設定流速を最小 $0.68 \mathrm{~cm} / \mathrm{s}$ から最 大 $15.0 \mathrm{~cm} / \mathrm{s}$ までの計14通りに変化させ，水深は $8 \mathrm{~cm}$ に固 定した。なお機体を水路より除いた状態で上流端より $7 \mathrm{~m}$ 地点の水面下1mmをLDAによって計測した.

\section{（2）主流方向の静止とPIDパラメータの調整}

まず比例制御について検討する． $K_{P} を 0.2 ， 0.5 ， 1.0$ お よび2.0の 4 通り選んだ. $K_{i}$ は $0, K_{d}$ は0.1に固定した. $40 \mathrm{~cm}$ 幅水路において基準板より $120 \mathrm{~cm}$ 下流のセンターラ インに流れに平行になるように機体をセットした. 主流 速が10.2cm/sのケースを対象とした. プログラム開始と 同時に支えをはずしこの時刻を $t=0$ とする．図一 6 はこの 後の反射板からの機体の距離 $\Delta x$ とモータへの入力值 $I p の$ 時系列変化をそれぞれの $K_{P}$ にいて示寸.

$K_{P}=2.0$ の場合は機体が流下方向に振動し定位置に静止し ない. $K_{P}=1.0 て ゙ は$ 初期時間に振動があるものの収束する. $K_{P}=0.1$ では変化が滑らかであり時定数も小さいが， $30 \mathrm{~s}$ までの間，機体が流されることがわかる．このように $K_{P}$ が過小であれば，支えをはずした直後にモータ加速 がおいつかず機体が大きく流下してしまうため，今回は $K_{P}=0.5$ を採用した.

前述のとおり目標点からの静止位置のずれは積分制御 で対処できそうであるが，これについては続報で詳細に 検討し, 今回は積分制御を考えない. 微分制御パラメー タ $K_{d}$ にいては，0.0，0.1，0.5および1.0の 4 通り選択し

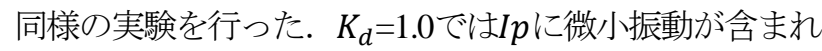
たが，他の3ケースではこのようなノイズはなく収束し

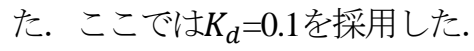
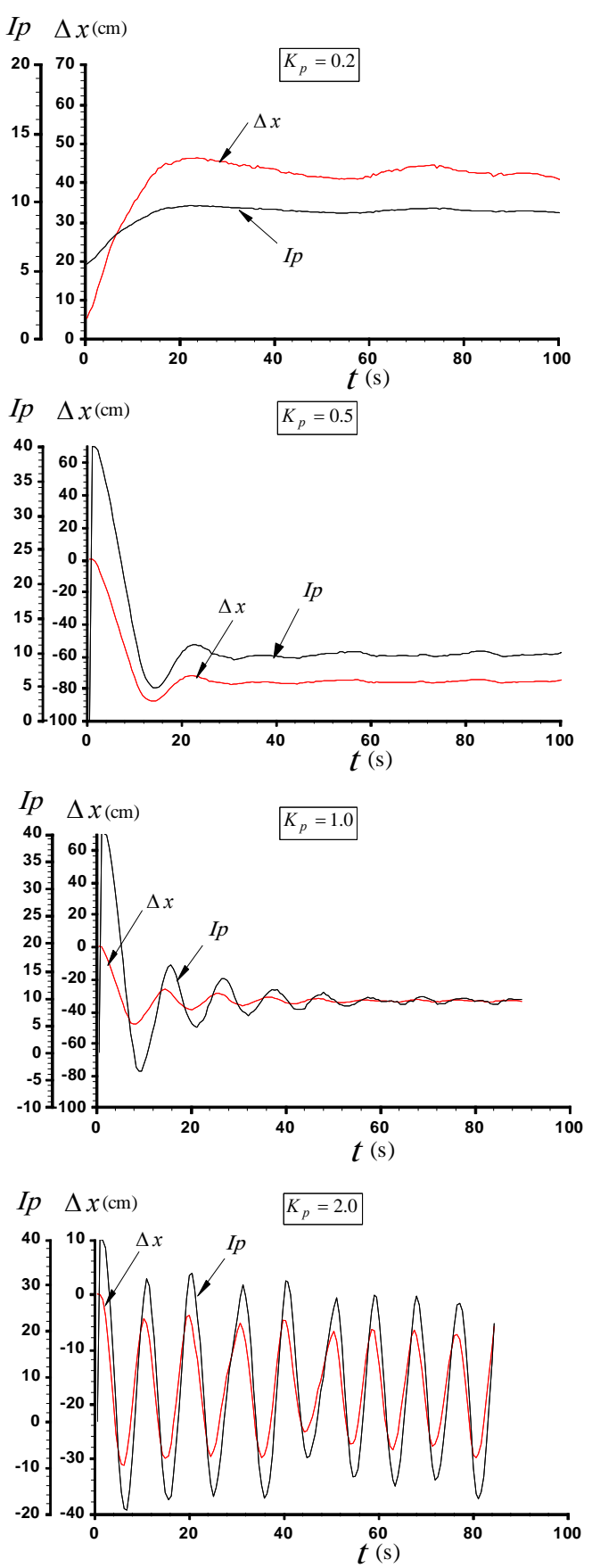

図-6 比例制御係数の検証

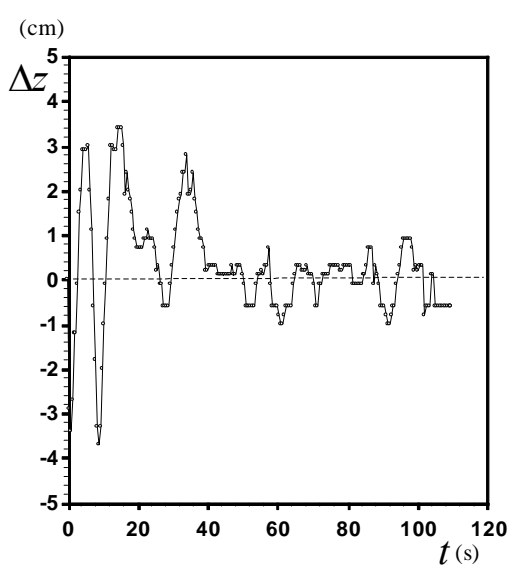

図-7 横断方向移動量の時系列変化 


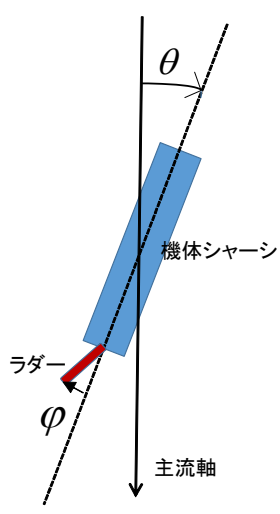

図-8 ヨーとラダー角の定義

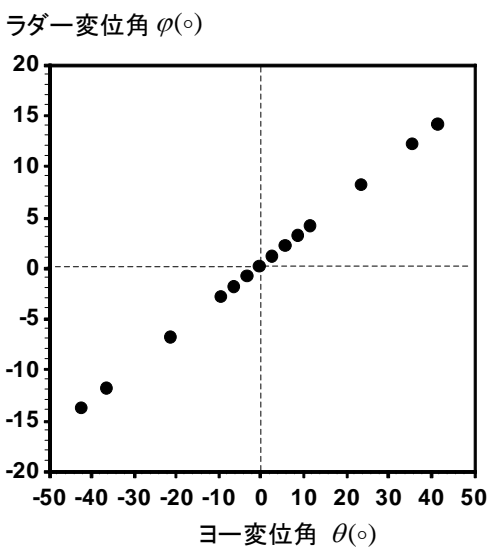

図-9ヨーとラダーの角度の関係

\section{（3）横断方向の静止特性}

$40 \mathrm{~cm}$ 幅水路の流速 $10.2 \mathrm{~cm} / \mathrm{s}$ のケースにて機体の横断方 向挙動を図-7に示寸．水路センターラインに静止する様 設定した. サイドスラスタによって40秒後には変動がセ ンターラインから $\pm 1 \mathrm{~cm}$ 以内に収まっている. 本水路に て実施した全てのケースにおいて同様の結果が得られて おり，横断軸方向の位置制御は良好であるといえる.

\section{(4) ヨ一制御}

機体のヨー角とラダーの変位角の定義を図-8に示寸. 本システムではコンパスセンサでヨー角を検出し，変位 に応じてラダーを動作させる．空気中で機体を鉛直重心 軸周りに回転させてその時のラダ一変位角を計測した. ラダー制御にもMモータを用いたがこれには変位角セン サが内蔵されている．図-9はこれらの関係を示す，正負 のヨー角変化に比例してラダーが制御されることがわか る. これにより機体は常に流軸方向を保持する.

\section{（5）スクリュ一回転速度による流速評価}

スクリューの回転速度から水面の時間平均主流速を評 価するためにLDAによる検定を行う。機体を取り除いた 状態で40cm幅水路において等流状態を作り, 超音波セ
$\mathrm{U}(\mathrm{cm} / \mathrm{s})$ LDAによる実測主流速

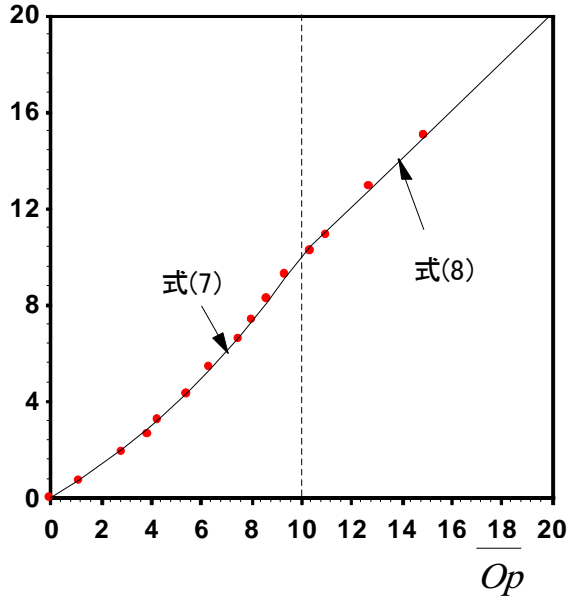

図-10 校正曲線

ンサの反射板位置より $100 \mathrm{~cm}$ 下流側のセンターラインに

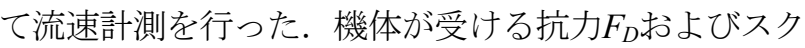
リューによる推進力 $F_{T}$ はそれぞれ次のように表せる.

$$
\begin{aligned}
& F_{D}=\frac{1}{2} \rho U^{2} A C_{D} \\
& F_{T}=\frac{1}{2} \rho m^{2} D^{4} C_{T}
\end{aligned}
$$

ここで $\rho$ は水の密度，Uは流速，Aは機体の投影面積， $m$ はスクリューの回転速度(rpm)，Dはスクリュー羽の直径 である. $C_{D}$ および $C_{T}$ はそれぞれ抗力係数および推力係 数である. 静止時にこれらがバランス寸るとすれば，次 のように対向流速はスクリュー回転速度に比例する.

$$
U \propto \pi D m
$$

図-10に実測した主流速Uおよび計測点にて機体を静止 させたときのスクリュー回転速度に対応寸る $\overline{O_{p}}$ 值の関 係を示寸.ここで である.U>10cm/sでは式(6)の線形関係が成立寸るがこ れより低流速側では線形関係からのずれが認められる. また摩擦抵抗が圧力抵抗に対して相対的に大きくなるた めと考えられる. 低流速側も評価するために補正関数を 導入して下記の校正式を提案する. 図に示すように実測 值に良好にフィットすることがわかる.

$$
\begin{aligned}
U(\mathrm{~cm} / \mathrm{s}) & =\overline{o_{p}} e^{-0.5\left\{1-\overline{o_{p}} / 10\right\}} \quad\left(\overline{o_{p}}<10\right) \\
U(\mathrm{~cm} / \mathrm{s}) & =\overline{O_{p}} \quad\left(\overline{o_{p}} \geq 10\right)
\end{aligned}
$$

\section{5．平面 2 次元運動テスト (150cm幅水路)}

野外計測を想定すれば，機体のリリース地点は岸部で ある．河川中央部など手が届かない場所を計測するため には，目標地点まで正確に自動航行させる必要がある. そこで幅 $150 \mathrm{~cm}$ 水路を用いて機体の平面2次元運動テス 卜を行った（写真-2）.水理条件は水深10cm, 断面平均 流速 $10 \mathrm{~cm} / \mathrm{s}$ の 1 ケースとした. 


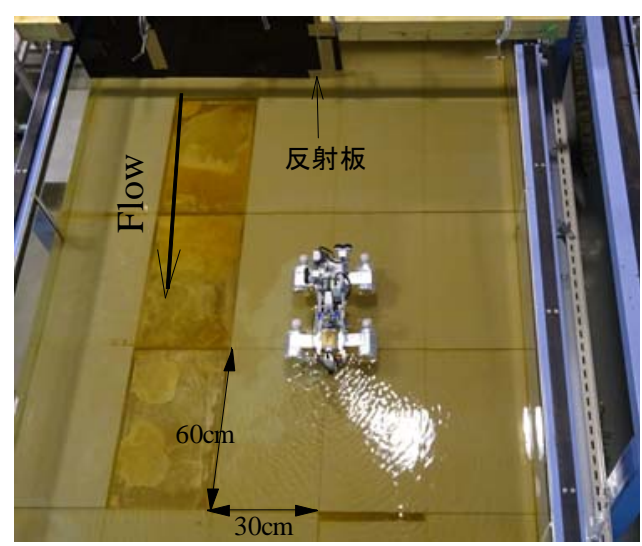

写真-2 150cm幅水路における実験の様子

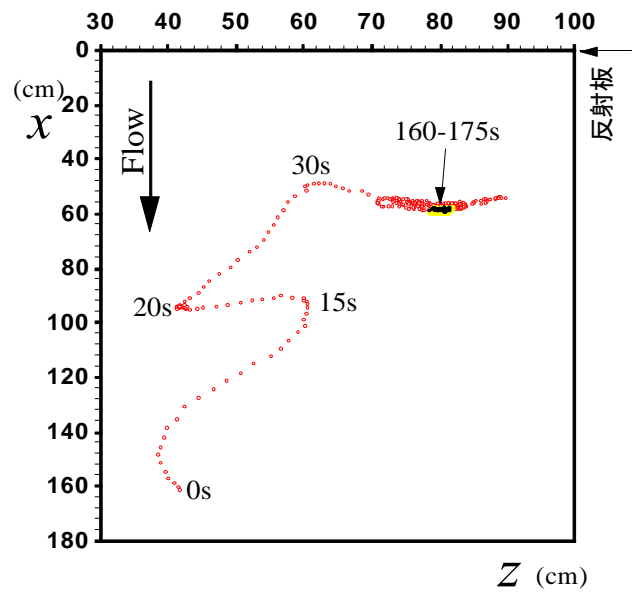

図-11 平面運動の軌跡

リリースおよびターゲット座標（単位cm）はそれぞれ， $(x, z)=(162,42)$ および（60,80）とした. 図-11はリリース 時刻から175秒間の機体位置を0.5秒ごとに時系列に示し たものである. 計測終了直前の15秒間についてはの印で マークした. なおターゲット地点における電磁流速計

（ケネックVP3000）および本機による実測流速は各々 $11.9 \mathrm{~cm} / \mathrm{s}$ おび $11.6 \mathrm{~cm} / \mathrm{s}$ で，誤差 $2.5 \%$ であった. $x$ 運動に注目すると $t=15$ 秒まで上流側へ移動し $t=15-20$ 秒 の間には横断方向のドリフトが発生するが，同時にメイ ンスクリューの仮の静止回転数が計算される. またサイ ドスラスタによりドリフトは $=20$ 秒では一時的に抑制さ れる. $t=25-35$ 秒ではスクリューが増速されて目標地点に 向かって遡上する. さらに $t=35$ 秒以後は $z$ 方向について 目標座標へ近づく. 先に $x$ 運動が収束しその後, $z$ 運動が 振動しながら収束する. $t=160-175$ 秒におけるターゲット ポイント周りの $z$ 方向の変動は最大 $\pm 2 \mathrm{~cm}$ であった. この 変動幅は今後, スラスタ位置, モータ選定, 制御パラ メータの再検討を通じてより改善できるものと考える.

\section{6. おわりに}

自律航行し水流に対して静止して流速計測を行うボー ト型ロボットを試作した．室内水路を用いてPID制御の パラメータ調整を行い，実用性を視野に入れた2次元運
動テストによりリリース地点からターゲット地点への速 やかな移動が確認できた．またレーザー流速計によって 推進スクリューの回転速度と対向流速の校正曲線を求め た. 本ロボットシステムは, 軽量コンパクトでありリ リース後は全自動のため計測作業が簡便である点, 極端 な暴風河川を除けば自然要因の影響は少なく確実性に長 ける点などが魅力である. 流速計測に限らず各種センサ の移動式ベースとすれば手の届かない河川中央部等にお ける河床形状や水質調査も可能である. 最近ではラジコ ン潜水艦に装着した水中カメラによる河川の魚類探査の 報告例11)もあり，河川探査一の幅広い応用も期待できる.

一方で実用化には多くの課題がある。本試作機が適用 できる領域は準定常の直線河道区間で，機体形状を改良 しても最大で $20 \mathrm{~cm} \sim 30 \mathrm{~cm} / \mathrm{s}$ 程度の低速場に限定される. 時間平均的な主流速は評価できるがマイクロスケールの 乱流変動には追従できない弱点がある. また機体位置セ ンシングに用いる反射板の設置は現実的でなく, GPSや 加速度センサあるいはトランスポンダによる位置同定が 必要である. さらに浮体式の場合, 風によるドリフトが 避けられず潜水化が求められる. 洪水河川で使用する際 には，流木等の漂流物を回避する運動制御も組み込まな くてならない. 演算装置にarduino等の小型マイコンを採 用し機体のコンパクト化を目指寸とともに推進モータの 高出力化やPID制御の改良を行うことで，より大きな流 速や細かな非定常変動への対応を実現したい.

\section{参考文献}

1) 二瓶泰雄 ・酒井雄弘, 実河川洪水流における浮子の更生係数, 土木学会論文集B, Vol.66, No.2, pp.104-118, 2010.

2) 二瓶泰雄, 河川流量モニタリング, ながれ, Vol.29, pp.187192, 2010.

3) 萬矢敦啓 - 岡田将治・橘田隆史 - 菅野裕也 ・深見和彦, 高速 流における ADCP 観測のための橋上操作艇に関する提案, 河川技術論文集，第16 巻, pp.59-64， 2010.

4) 岡田将治・萬矢敦啓・本永良樹・橘田隆史, ADCPによる洪 水流況・掃流砂・浮遊砂量の同時計測技術構築のための基礎 的検討, 土木学会水工学論文集, 第57巻, I_751-I_756, 2013.

5) Fujita, I., Muste, M. and Kruger, A., Large-scale particle image velocimetry for flow analysis in hydraulic engineering applications, Journal of hydraulic research, Vol.36, pp. 397-414, 1998.

6) 藤田一郎・安藤敬済・堤志帆・岡部健士，STIVによる劣悪 な撮影条件での河川洪水流計測, 水工学論文集, 第 53 巻, pp.1003-1008, 2009.

7) 藤田一郎, 河川流速・流量の画像計測における遠赤外線カメ ラの活用，ながれ，Vol.32, pp.347-352, 2013.

8) 山口高志・新里邦生, 電波流速計による洪水流量観測, 土木 学会論文集, No.491, pp.41-50, 1994.

9) 萬矢敦啓・大平一典・菅野裕也・深見和彦，非接触型電波式 流速計を用いた洪水流量自動観測手法の一考察，河川技術論 文集，第16 巻, pp.53-58, 2010.

10)森泰親, 演習で学ぶPID制御, 森北出版, 2009.

11)鬼束幸樹・秋山壽一郎・小野篤志・芹川泰介, 潜水艦模型 と超小型ワイヤレスカメラを用いた魚類の生息調査, 水工 学論文集, 第53巻, pp.1255-1260, 2009.

(2014. 9. 30受付) 